\title{
What is the ideal age limit for a person to be considered an older adult today?
}

While this is an old debate, it remains current even today. In this editorial we discuss a subject that has long been controversial, and which involves discussions that are often permeated with explicit interests and other motives. Is there, then, an ideal age limit for a country, region or territory today?

In 2018, the Italian Society of Geriatrics and Gerontology adopted an age limit of 75 to be used when considering someone an older adult. According to the directors of the society, the limit of 65 was obsolete, as today's 65-year-olds have similar cognitive and physical functions to a 40- to 45 -year-old person from 30 years ago. In this sense, and based on the Italian life expectancy (83 years for men and 86 for women), they proposed an age extension of another ten years before someone could be considered an older adult ${ }^{1}$.

Similarly, it was recently reported that the UK intended to change the chronological age at which a person is considered older to 70. As Sara Harper of the Oxford Institute of Population Ageing says, "Old age does not arrive in one's seventies. It arrives when we become dependent"2.

Based on what was happening around the world, IPEA researcher Ana Amélia Camarano argued in 2013, that when commemorating the tenth anniversary of the Statue of the Older Adult, it would be appropriate to raise the age limit for being considered older from 60 to 65 , although the change did not occur. She stated that the aim would be to monitor the health conditions and life expectancy of the population approaching 75 at the time ${ }^{3}$.

In 2018, in another interview, this time for the Folha de São Paulo newspaper, the researcher stated that the concept of an older adult had itself become old. She argued that in 2018 a 70-year-old would be similar to a 50 -year-old in the past, and even a 60 -year-old would no longer be like their grandparents. She also stated that, rather than redefining the borderline ages to be considered older, it was necessary that such an age limit be reflected in government policy. For Camarano, "the definition of older adult for people aged 60 and over dates from 1994. Since then, life expectancy has increased by six years"'.

In this context, the Brazilian Institute of Geography and Statistics (or IBGE) declared in 2018 that Brazilian life expectancy at birth is 76.3 years, representing over 30 years of survival more than the current elderly population, which in 1950 had a life expectancy of 43.3 years ${ }^{5,6}$. Based on the life expectancy of the Brazilian people disclosed by the IBGE and considering a definition of ten years lower than life expectancy for considering a person older in Brazil, the limit would be 66 years. 
Turning to the legal aspects of the discussion, in 2019, the Rio de Janeiro State Court of Justice ruled as unconstitutional 18 articles of a law approved by the state Legislative Assembly which, in 2018, had guaranteed that "older people aged 60 and above would have free admission to museums, public transportation, games, sporting events and other activities," ruling that the benefit should be valid only for people aged 65 and over? ${ }^{7}$ Accordingly, the Statute of the Older Adult (Law 10,741, dated October 1, 2003) established a 65-year limit for access to certain rights, such as free public transport and the benefit of a minimum monthly salary for those who do not have the means to support themselves ${ }^{8}$.

Considering a single age limit for the entire country seems somewhat unjust, however. Although life expectancy has risen, living conditions in many areas remain precarious, making life expectancies well below those of the country as a whole. Violence, unemployment, hunger, poverty and, above all, multiple forms of social inequities (ethnicity/skin color, social class, gender) have created multiple life expectancies in Brazil, where some areas have Japanese type levels and others have expectancies closer to sub-Saharan Africa.

Nevertheless, would it be wise to raise the chronological age for considering a person an older adult by five years? What are the costs and benefits of such an approach? In order to answer these questions, it is necessary to consider many aspects that directly impact people's lives, especially those in the age brackets that border the defining limit.

We therefore invite researchers, managers and professionals from various levels of health systems to consider and evaluate with us the government policies that permeate the subject, and invite them to submit their studies to a thematic issue of the Brazilian Journal of Geriatrics and Gerontology, which will evaluate these policies that interface with older adults.

Kenio Costa Lima

Editor associado da RBGG, professor titular da UFRN, pós-doutorado em Saúde Pública pela Agência de Saúde Pública de Barcelona.

Tamires Carneiro de Oliveira Mendes (D)

Presidente do Conselho Estadual da Pessoa Idosa (CEDEPI/RN), pós-doutorado em Saúde Coletiva pela UFRN, Sanitarista da Secretaria Municipal de Saúde do Natal, Consultora da RBGG.

\section{REFERENCES}

1. Itália muda conceito de idoso para 75 anos. Jornal Nacional [Internet]. 04 dez. 2018 [acesso em 08 dez. 2019]. Disponível em: https://g1.globo.com/jornal-nacional/noticia/2018/12/04/italia-muda-conceito-de-idoso-para-75anos.ghtml

2. Alfageme A. "La vejez ya no llega a los 70. Llega al convertirnos en dependientes”. EL PAÍS [Internet]. 26 Jun. 2019 [acesso em 08 dez. 2019]. Disponível em: https://elpais.com/sociedad/2019/06/18/actualidad/1560876583_463246. html?fbclid=IwAR1CPftCHEapGiEghcePXWq72isSV_mHVzRifqKoXlL6Vvl8PhPSCDjPavE

3. Camarano AA. Estatuto do Idoso: avanços com contradições [Internet]. Rio de Janeiro: IPEA; 2013 [acesso em 08 dez. 2019]. (Texto para Discussão, 1840). Disponível em: https://conteudo.imguol.com.br/blogs/52/files/2013/06/ td_1840.pdf

4. Alegretti L, Cancian N. Conceito de idoso ficou velho, diz pesquisadora do Ipea. Folha de São Paulo [Internet]. 26 jun. 2018 [acesso em 08 dez. 2019]: Equilíbrio e Saúde. Disponível em: https://www1.folha.uol.com.br/ equilibrioesaude/2018/06/conceito-de-idoso-ficou-velho-diz-pesquisadora-do-ipea.shtml

5. Instituto Brasileiro de Geografia e Estatística. Tábua completa de mortalidade para o Brasil - 2018: breve análise da evolução da mortalidade no Brasil [Internet]. Rio de Janeiro: IBGE; 2019 [acesso em 08 dez. 2019]. Disponível em: https://biblioteca.ibge.gov.br/visualizacao/periodicos/3097/tcmb_2018.pdf 
6. Instituto Brasileiro de Geografia e Estatística, Diretoria de Pesquisas, Coordenação de População e Indicadores Sociais. Tendências Demográficas: uma análise dos resultados da amostra do Censo Demográfico 2000 [Internet]. Rio de Janeiro: IBGE; 2004 [acesso em 08 dez. 2019]. Disponível em: https://biblioteca.ibge.gov.br/pt/bibliotecacatalogo?view $=$ detalhes\&id $=24889$

7. Justiça determina que terceira idade no RJ volte a ser 65 anos [Internet]. Rio de Janeiro: G1; 2019 [acesso em 08 dez. 2019]. Disponível em: https://g1.globo.com/rj/rio-de-janeiro/noticia/2019/09/09/justica-determina-que-terceiraidade-no-rj-volte-a-ser-65-anos.ghtml

8. Brasil. Lei $\mathrm{N}^{\circ}$ 10.741, de 01 de outubro de 2003. Dispõe sobre o Estatuto do Idoso e dá outras providências. Diário Oficial [da] República Federativa do Brasil. 03 out. 2003 [acesso em 08 dez. 2019]. Disponível em: http://www. planalto.gov.br/ccivil_03/leis/2003/110.741.htm 